20 Dimant J. Accidents in the skilled nursing facility. NY State f Med 1985; 85: 202-5.

21 McIntosh SJ, Lawson J, Kenny RA. Heart rate and blood pressure responses to carotid sinus massage in healthy elderly subjects. Age Ageing massage in healthy

22 Morley CA, Sutton R. Carotid sinus syncope. Int $\mathcal{F}$ Cardiol 1984; 6: 287-93.

23 Lempert T, Bauer M, Schmidt D. Syncope: a videometric analysis of 56 episodes of transient cerebral hypoxia. Ann Neurol 1994; 36: 233-7.

24 Aronow WS, Ahn C. Postprandial hypotension in 499 elderly persons in a long-term health care facility. F Am Geriatr Soc 1994; 42: 930-2.
25 Sattin RW. Falls among older persons: a public health perspective. Annu Rev Public Health 1992; 13: $489-508$.

26 Brignole M, Oddone D, Cogorno S, Menozzi C, Gianfranchi L, Bertulla A. Long-term outcome in symptomatic carotid sinus hypersensitivity. in symptomatic carotid sinus hyp

27 Kapoor W, Snustad D, Peterson J, Wieand HS Cha R, Karpf M. Syncope in the elderly. $A m \mathcal{F}$ Med 1986; 80: 419-28.

28 Ward C, McIntosh S, Kenny RA. The prevalence of carotid sinus syndrome in elderly patients with fractured neck of femur (abstract). Age Ageing 1994; 23 (suppl 1): A16.
29 Vellas B, Cayla F, Bocquet H, de Pemille F, Albarede $\mathrm{JL}$. Prospective study of restriction of activity in old people after falls. Age Ageing 1987; 16: $189-93$.

30 Wynne HA, Schofield S. Drug-induced orthostatic hypotension. In: Kenny RA, ed. Syncope in the older patient. London: Chapman and Hall, 1996; pp 137-54.

\title{
Images in clinical medicine
}

\section{Department of \\ Medicine, St \\ Bartholomew's \\ Hospital, London \\ EC1A 7BE, UK \\ WM Drake}

Department of

Cardiology, St Mary's

Hospital, London W2

1NY, UK

RS More

Accepted 25 June 1997

\section{Right atrial thrombus from deep venous thrombosis}

\author{
WM Drake, RS More
}

A 65-year-old man presented with sudden onset of irregular palpitations and breathlessness. Two weeks previously he had spent four days in bed on account of a 'flu-like' illness.

Examination revealed atrial fibrillation with a rapid ventricular response rate and a jugular venous pressure raised by $3 \mathrm{~cm}$, but no other signs or symptoms. Transoesophageal echocardiography revealed multiple clots within dilated right-sided chambers (figure). Subsequent Doppler ultrasound of the legs demonstrated bilateral deep venous thrombosis extending up to the common iliac veins.

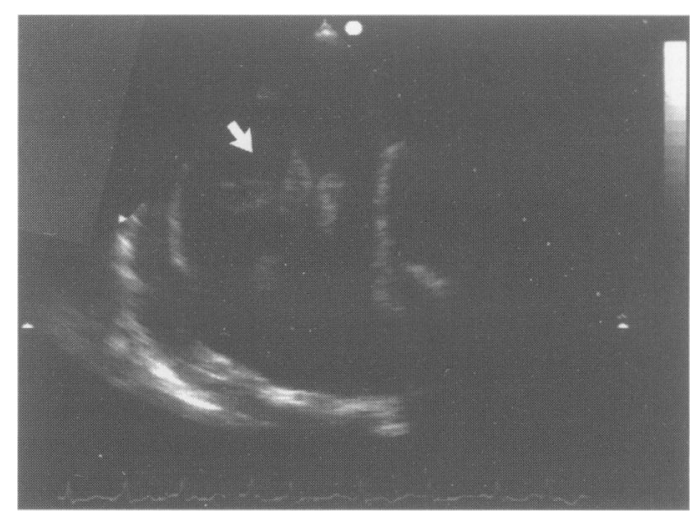

Figure Transoesophageal echocardiogram (transverse view) showing thrombus within a dilated right atrium 